\title{
Великий Новгород. Концепт Археологического кластера - инновационный функционал развития туристической сферы города
}

\author{
Г.И.Кулешова, ОНИР ГИПРОНИИ РАН, Москва
}

Особенность настоящего момента состоит в том, что градостроительные работы разрабатываются под конкретные государственные программы, которые обеспечивают дополнительное финансирование городского развития. Концепция ревитализации посвящена повышению качества городской среды городского центра Великого Новгорода в целях развития туристической сферы и увеличения туристического потока, чему в настоящее время государством уделяется особое внимание. Создание Археологического кластера - одно из предложений Концепции, которое частично может быть реализовано уже в ближайшие годы, причем именно на направлении престижного интеллектуально-деятельностного туризма. Это не только увеличит значение Великого Новгорода в туристической индустрии, но и повысет его идеологическую роль в общероссийском культурно-образовательном пространстве ${ }^{1}$.

Ключевые слова: городская среда, туризм, археологические раскопки, археологический туризм, музеефикация раскопок

Veliky Novgorod. The Concept of the Archaeological Cluster - Innovative Functionality for the Development of the City's Tourism Sector

G.I.Kuleshova, ONIR GIPRONII RAN, Moscow

The peculiarity of the present moment is that urban planning works are developed under specific state programs that provide additional funding for urban development. In this case, the Concept being developed is devoted to improving the quality of the territories and development of the city center of Veliky Novgorod in order to develop the tourism sector and increase the tourist flow, which is currently being paid special attention by the state. The creation of an Archaeological Cluster is one of the proposals of the Concept, which can be partially implemented in the coming years, and it is in the direction of prestigious intellectual and activity tourism. This will not only increase the weight of Veliky Novgorod in the tourism industry, but also its ideological role in the all-Russian cultural and educational space.

Keywords: urban environment, tourism, archaeological excavations, archaeological tourism, museumification of excavations.

В последнее время в отношении заказов на градостроительные работы от муниципальных администраций наблюдается такое явление, как выстраивание целей разработки под государственные национальные стратегические программы, минуя собственно задачи развития генерального плана в их классическом понимании ${ }^{2}$. Это связано со стремлением муниципалитетов получить дополнительное финансирование для развития через вхождение в эти программы.

В проекте «Разработка концепции ревитализации туристического центра Великого Новгорода в целях создания современной комфортной городской среды», несмотря на сложно сконструированное название, ключевое слово «туристического». Именно через это Проект связывается с федеральной целевой программой «Развитие внутреннего и въездного туризма в Российской Федерации (2019-2025 годы)», Нацпроектом «Туризм и индустрия гостеприимства» (в стадии согласования) в рамках «Стратегии развития туризма

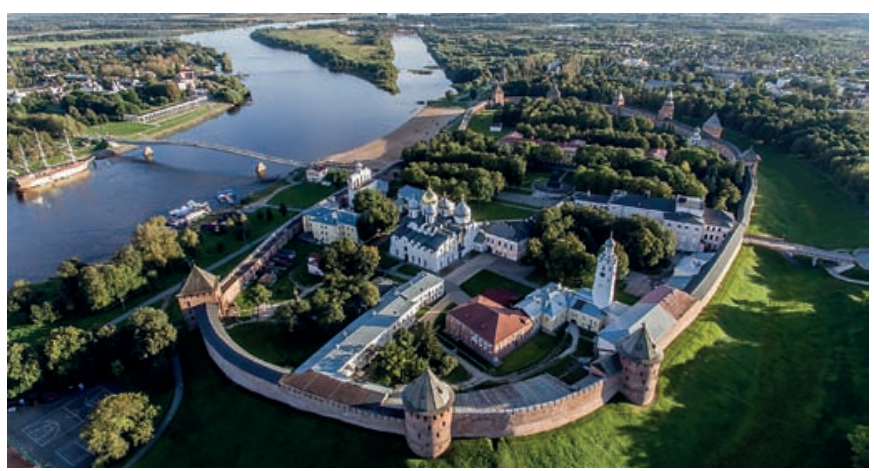

\footnotetext{
${ }^{1}$ Разработан в составе проекта «Разработка концепции ревитализации туристического центра Великого Новгорода в целях создания современной комфортной городской среды» [Муниципальный контракт №0350300011820000207 от 28 декабря 2020 года между МКУ Великого Новгорода «Управление капитального строительства» и ОАО «Российский институт градостроительства и инвестиционного развития» (ГИПРОГОР)], авторским коллективом архитекторов в составе: Ю.В.Барковская - главный архитектор проекта, П.К. Неустроева, А.Т Мамедов, Верховская М.А - главный специалист по историко-культурному наследию, Кулешова Г.И. - главный специалист по научно-инновационному комплексу.

${ }^{2}$ К таким программам относится целый ряд вытекающих из Указа Президента РФ от 21 июля 2020 г. N 474 «0 национальных целях развития Российской Федерации на период до 2030 года»: Нацпроект «Жильё и городская среда» (включающий четыре федеральных проекта: «Ипотека», «Жильё», «Формирование комфортной городской среды» и «0беспечение устойчивого сокращения непригодного для проживания жилищного фонда»), «Экономическое развитие и инновационная экономика», Стратегия развития туризма в Российской Федерации на период до 2035 года и другие.
} 
в Российской Федерации на период до 2035 года». Усилия команды проектировщиков были также направлены на обеспечение возможности включения разработки «Концепции ревитализации туристического центра Великого Новгорода» в Нацпроект «Туризм и индустрия гостеприимства» (в стадии согласования). Кроме того, поскольку во второй половине 2020 года Ростуризм анонсировал пилотный проект по редевелопменту исторических центров городов РФ для повышения их туристической привлекательности, необходимо было учесть и это обстоятельство, так как речь идёт о предоставлении на такие проекты субсидий в 2021-2023 годах.

Одна из актуальных проблем Великого Новгорода заключается в том, что несмотря на востребованность памятников, туристическая сфера города находится в стагнации, усугублённой общемировой экономической ситуацией. 0бладая уникальным ресурсом памятников мирового значения, город тем не менее теряет туристический поток. Проблема в целом и пути градостроительного обеспечения её решения заслуживают отдельной обстоятельной статьи по результатам выполнения проекта «Разработка концепции ревитализации туристического центра Великого Новгорода в целях создания современной комфортной городской среды» в целом. В настоящей статье внимание сосредоточено на концепции развития Археологического кластера как инновационного инфраструктурного объекта туристической сферы, специфического и характерного именно для условий Великого Новгорода.

\section{Основные предпосылки для формирования Археологического кластера}

В настоящее время представляется очевидной недооценка феномена Великого Новгорода как опорной точки метакультурного пространства России [1]. Между тем Великий Новгород - исток начал сакральной географии России: отсюда «есть, пошла земля русская», феномен домонгольской и древней Руси, второй по политическому значению древнерусский город после Киева. Это город, с которым связаны имена великих князей, крупнейших исторических деятелей, определивших цивилизационный путь России, - Владимира Крестителя, Ярослава Мудрого, Александра Невского. Многие самобытные, оригинальные и уникальные, а самое главное - первичные в своем существе, общественные явления и процессы возникли и развились в Великом Новгороде, став частью национального кода и воплощением народного духа.

Великий Новгород - город всемирного наследия ЮНЕСКО, один из немногих городов России, удостоившихся чести быть включённым в Список всемирного культурного наследия. Предмет наследия и охраны - исторические памятники города и окрестностей, оборонительные укрепления, монастыри и храмы ${ }^{3}$.

Великий Новгород - перекрёсток культур, медиатор на торговом пути «из варяг в греки». Новгородская земля в Средневековье являлась важным коммуникативным элементом единого экономического и культурного пространства между Северной Европой и Византией, условно называемым «ганзейским», именно здесь истоки экономических, политических и социокультурных связей России с государствами Балтийского региона, выросших из русско-ганзейских связей

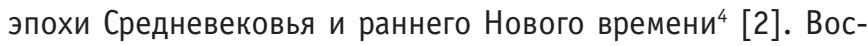
точный отрезок «Великого Ганзейского пути» проходил через владения Господина Великого Новгорода.

Великий Новгород - центр археологии Северо-Запада России и Балтийского региона. В 2012 году исполнилось восемьдесять лет с начала систематического археологического изучения Великого Новгорода. За прошедшие с начала раскопок десятилетия было исследовано более 50 участков в разных районах города общей площадью более 40 кв. тыс. м (данные на 2016 год). Археологические раскопки Великого Новгорода являются фундаментальной базой исторической науки по Средневековью, ежегодно пополняют фонды письменных и вещественных источников этого периода. С 1962 года до своей кончины археологическую деятельность возглавлял академик В.Л. Янин. Признанием роли и значения археологической деятельности в культурной и гуманитарной жизни В. Новгорода являются:

- создание Национального историко-археологического центра имени академика В.Л. Янина в составе ФГБУ «Новгородский государственный объединенный музей-заповедник» - уникального научно-исследовательского центра национального масштаба, который должен превзойти по научной значимости известные зарубежные центры аналогичной тематики;

- создание по инициативе Российской академии наук и Новгородского музея-заповедника Археологического квартала, являющегося важнейшей базой в изучении материальных аспектов древнерусского периода истории, а также истории русско-ганзейских связей на основе раскопок Немецкого двора, привлекающих отечественных и зарубежных специалистов.

Создание НИФЦ им. академика В.Л. Янина и Археологического квартала позволили внести в предложения проекта «Разработка концепции ревитализации туристического

\footnotetext{
${ }^{3}$ Исторические памятники Новгорода и окрестностей (англ. Historic Monuments of Novgorod and Surroundings) - собирательное название, под которым ЮНЕСКО в 1992 году внесло в список объектов Всемирного наследия средневековое архитектурное наследие города Великий Новгород. Всего в Детализированный перечень памятников истории и культуры Великого Новгорода и его окрестностей, имеющих выдающуюся универсальную ценность, включенных Решением юбилейного заседания Комитета Всемирного наследия ЮНЕСКО в 1992 году в Список Всемирного наследия, входит 178 объектов, в том числе культурный слой (глубиной 8 м) в пределах улиц: Завальная, Завальная-Кольцевая, Запольская, территорией около 347 га в пределах вала 0кольного города.

${ }^{4}$ «Экономические, политические и социокультурные коммуникации России и Прибалтики в XV-XVII вв. по материалам архивных коллекций Таллинна, Любека, Берлина и Санкт-Петербурга». Руководитель - Бессуднова Марина Борисовна, д.ист.н., Нов.ГУ им. Ярослава Мудрого. Грант № 19-18-00183 .(источник: https://rscf.ru/project/19-18-00183/).
} 
центра Великого Новгорода в целях создания современной комфортной городской среды», наряду с целым рядом других, предложение о развитии научно-делового туризма и особенно - археологического, как нового функционала в туристической сфере города.

\section{Археологический и научно-деловой туризм как особая разновидность туризма}

Археологический туризм является новым явлением в туристической индустрии, это так называемый интеллектуально-деятельностный туризм, который приобрёл в настоящее время достаточно высокую популярность в мире [2]. Это предвидел академик В.Л.Янин, высказывая надежду, что и в России археологический туризм займет в своё время нишу интеллектуального развивающего вида туризма [3, с. 35]. Великий Новгород - идеальное место удовлетворения спроса на интеллектуально-деятельностный досуг. Это повышает вес города не только в туристической индустрии, но и его идеологическую роль в общероссийском культурно-образовательном пространстве.

Научно-деловой туризм эффективен для региона тем, что он активизируется в периоды спада основной туристической активности, то есть в осенне-зимний период, хотя и не исключает организацию мероприятий весной и летом. Обычно, это конференции, семинары, симпозиумы, для проведения которых необходимы хорошие конференц-залы, оборудованные аудио- и мультисистемами и рассчитанные на вместимость от 10 до 120 человек. Представляется целесообразным, ориентируясь на уникальную среду исторического города, шире рекламировать организацию делового бизнес-туризма. Для этого вида туризма необходимы более комфортные условия проживания - гостиницы не менее пяти звёзд с набором услуг и сервиса, удовлетворяющим мировым стандартам, а также разработка и включение культурной и экскурсионной программ, рассчитанных на обеспечение досуга представителей бизнеса. Этот вид туризма может носить как индивидуальный, так и коллективный характер.

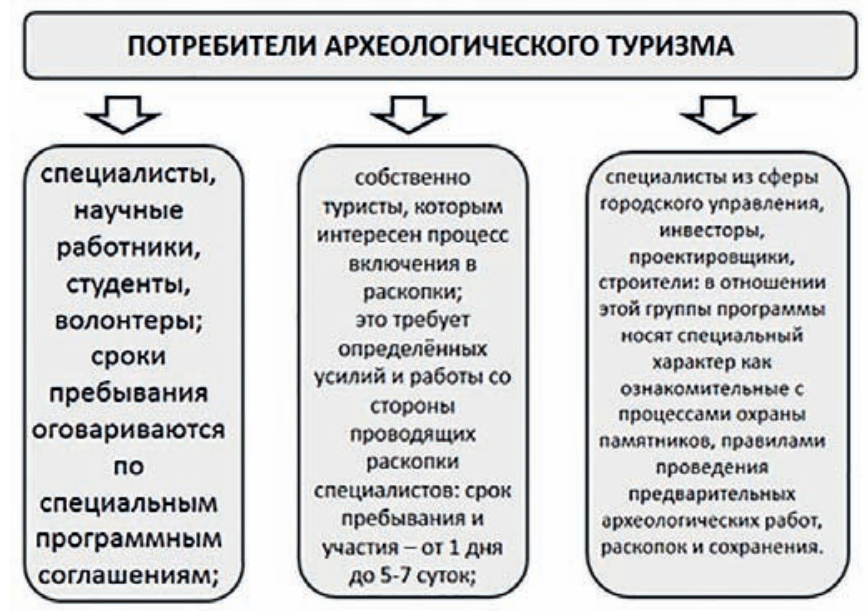

Рис. 1. Основные группы потребителей археологического туризма и их характеристики
В широком смысле археологический туризм - это особый вид туризма, направленный не только на знакомство с историко-культурными достопримечательностями, местами раскопок, памятниками архитектуры, музеями, но и предполагающий добровольное включённое участие в настоящих археологических экспедициях и раскопках.

Мировой археологический туризм предлагает поездки и экспедиции в Египет, Италию, Грецию, Индию, Израиль, Болгарию, Монголию, страны Южной Америки, Казахстан, Узбекистан. В Азербайджане руководством страны принято решение развивать археологический туризм как репрезентативное для страны и потенциально доходное направление ${ }^{5}$. Археологический туризм - весьма прибыльный бизнес, например, в Израиле семь дней участия в археологической экспедиции стоит туристу-любителю 500-550 долларов, в Соединённых Штатах и Европейском Союзе - 750-1500 долларов. Более дорогой вариант - это обучение в специальных археологических учреждениях, один курс стоит примерно пять-семь тысяч долларов.

Чаще всего среди добровольцев - любителей археологических раскопок, встречаются американцы, немцы, скандинавы, их примерный возраст - 25-35 лет, обычно это любители активного досуга, «офисные» работники ${ }^{6}$.

Научно-деловой и археологический туризм различаются по времени активного пользования и величине потоков. Археологический туризм наиболее востребован в период раскопок и полевых работ, то есть в весенне-летний период, он не отличается массовостью и многолюдностью, но требует хорошей организации и определённой эрудиции туроператора, то есть его специализации. Пользователей этого вида туризма можно разделить как минимум на три группы, представленные на рисунке 1.

0 третьей группе следует сказать особо, поскольку в стране подобный вид просвещения представителей городского управления, инвесторов, проектировщиков, строителей совершенно не представлен. Особенно это важно для инвесторов, в зоне ответственности которых находятся разработка проектов и производство потенциально опасных для археологического наследия работ. Это необходимо в том числе и для того, чтобы добиться понимания важности ведения таких работ на памятниках со стороны органов исполнительной власти. Необходимо особо отметить, что этот своеобразный вид туризма имеет обязательный характер в ряде европейских стран [4].

За рубежом по материалам археологических исследований воссоздают целые поселения с улицами и домами, в которых «протекает» жизнь: возобновляется давняя кухня, ремёсла, быт древних людей. Более того, в последнее время в европейских

\footnotetext{
${ }^{5}$ https://az.sputniknews.ru/life/20200603/424090280/arheologijaraskopki-turizm.html

${ }^{6}$ http://kij-turizmglonasstravel.com/destination/vidy-turizma/kulturnoistoriches/arxeologicheskij-turizm/
} 
странах невероятную популярность приобретают археологические фестивали, или фестивали «живой археологии» [2]: здесь демонстрируются древние ремёсла, тут же организована торговля изделиями мастеров, показываются рыцарские бои, древние обряды (свадьбы, помолвки, крестины). Таким образом, археологический туризм, помимо прямых целей участия туриста в раскопках, влечет за собой развитие смежных отраслей - фестивального, событийного, сервисной инфраструктуры, обеспечивающей места приложения труда малого бизнеса.

\section{Особенности формирования и развития}

\section{Археологического кластера в Великом Новгороде}

Базовые объекты развития археологического и научноделового туризма в Великом Новгороде прямым образом связаны с Новгородским государственным университетом им. Ярослава Мудрого и Новгородским государственным объединённым музеем-заповедником.

Ha сайте ARHEOLOGIJA.RU7 представлено несколько университетов, где можно получить полноценное археологическое образование, среди которых есть как исторические факультеты и кафедры с длительной самостоятельной историей, получившие международное признание в области подготовки кадров и научно-исследовательской деятельности, так и организованные в последние десятилетия в рамках преобразований высшего образования. Однако ни один из этих Университетов не расположен в такой уникальной историко-археологической ситуации, как НовГУ им. Ярослава Мудрого. Уникальность данного случая состоит в том, что и учебная база, и потенциальная научная школа, и раскопки, причём с перспективой на десятилетия вперёд, находятся на одной территории - это редчайший случай в мировой практике. Полевой и научно-исследовательский багаж факультета практически неисчерпаем, это хорошо иллюстрирует рисунок 2.

Представляется необходимым отметить, что на сайте Новгородского государственного университета им. Ярослава Мудрого ${ }^{8}$ в рубрике «Известные преподаватели и выпускники» ${ }^{9}$ отмечены всего девять персон - все гуманитарии, и из них три археолога, четыре историка. Это свидетельствует о своего рода специализации ментального пространства исторического города, очевидно, что «дух места» (spiritus loko) Великого Новгорода лежит именно в гуманитарной сфере. Между тем в перечне научных школ Новгородского университета представлены научные школы естественных и технических наук, а школ гуманитарного профиля и, в частности, историко-археологической научной школы на настоящий момент не представлено. В этом отчётливо проявляется недооценка роли и значения археологии в истории Университета и городской культуре Великого Новгорода.

Развитие археологического и научно-делового туризма базируется на трёх базовых объектах, из которых два в настоящее время находятся в стадии создания - Национальный историко-археологический центр им. ак. В.Л. Янина и Археологический квартал, а Гуманитарный Институт «Антоново» может получить новый стимул к развитию как своего функционала, так и территориальной экспансии в аспекте активного формирования археологического туризма (рис. 3). Необходимо отметить, что все три объекта, описанные ниже, выходят за границы технического задания проекта, однако, дают необходимые для стратегического развития города направления и точки роста территорий.

0 первых двух объектах будет упомянуто обзорно, поскольку центральным моментом статьи является проект Археологического квартала, рассмотренный далее подробно.

\footnotetext{
${ }^{7}$ https://arheologija.ru/gde-uchitsya-arheologii-v-rossii/

${ }^{8}$ https://www.novsu.ru/

${ }^{9}$ https://ru.wikipedia.org/wiki/Новгородский_государственный_университет
}

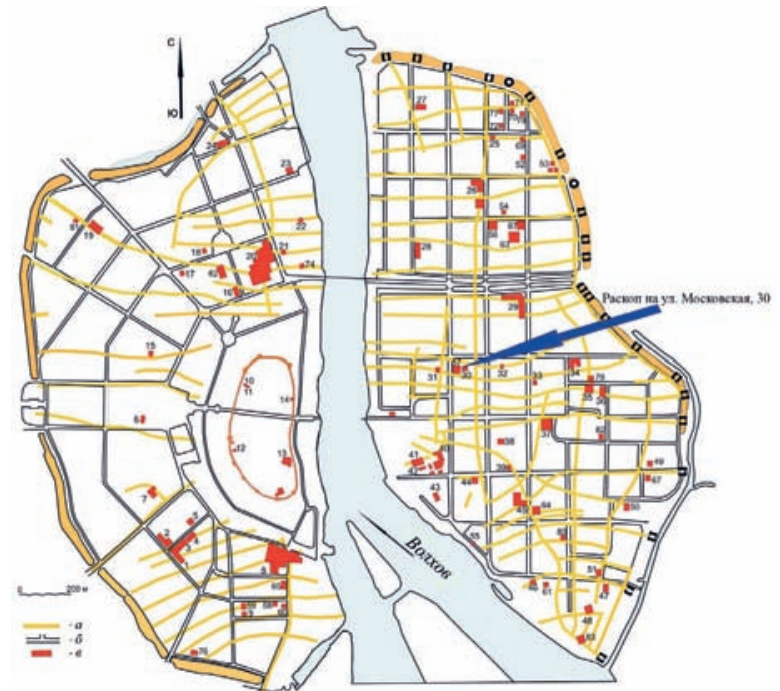

Рис. 2. Ситуационный план раскопов в Великом Новгороде (источник: [5])

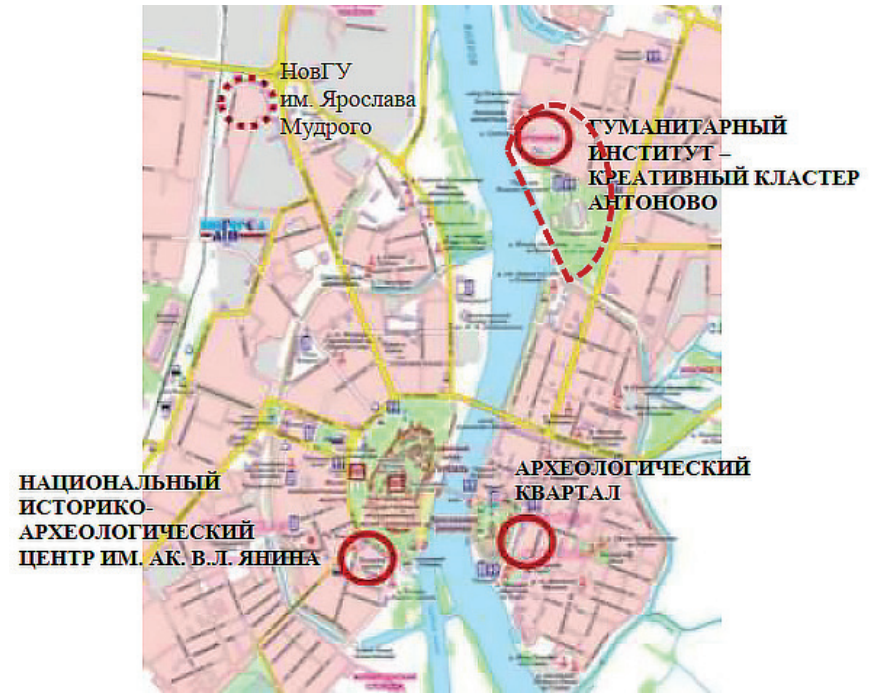

Рис. 3. Схема размещения базовых объектов Археологического кластера 
Национальный историко-археологический центр им. ак. В.Л. Янина

Создающийся научно-исследовательский центр национального масштаба не только уникальный комплекс фон-

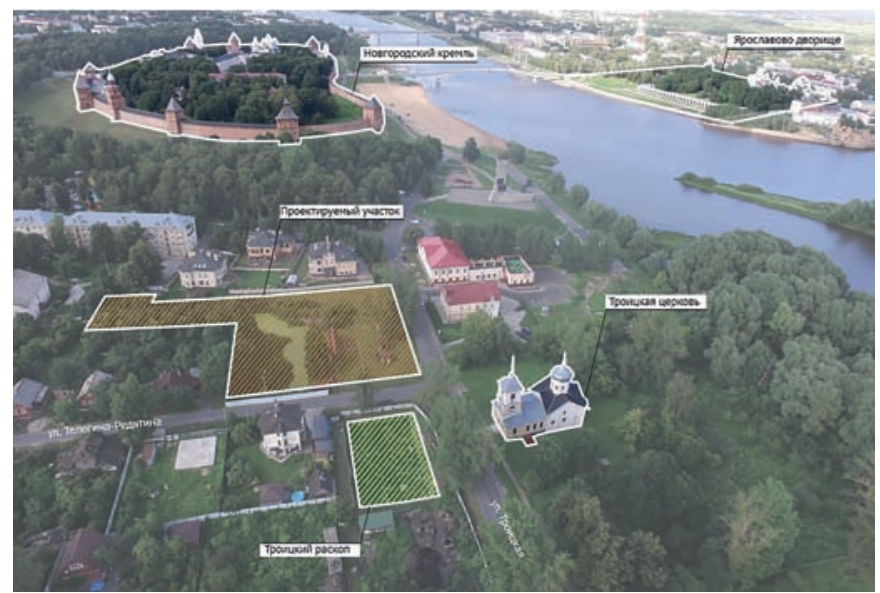

Рис. 4. Участок размещения НИАЦ им. Ак. Янина в городской застройке (источник: Строительство Национального историкоархеологического центра имени академика В.Л. Янина: буклет / Минкультуры России, ФГБУК «Новгородский государственный объединенный музей-заповедник». - В. Новгород, 2021)

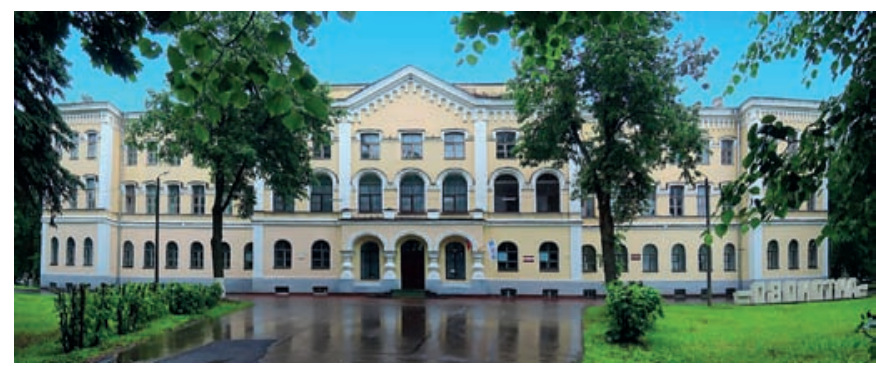

Puс. 5. Главный корпус Гуманитарного института НовГУ в Антонове (главный семинарский корпус, закончен в 1890 году, автор проекта - епархиальный архитектор А.И. Борщов). Фото из открытых источников сети Интернет

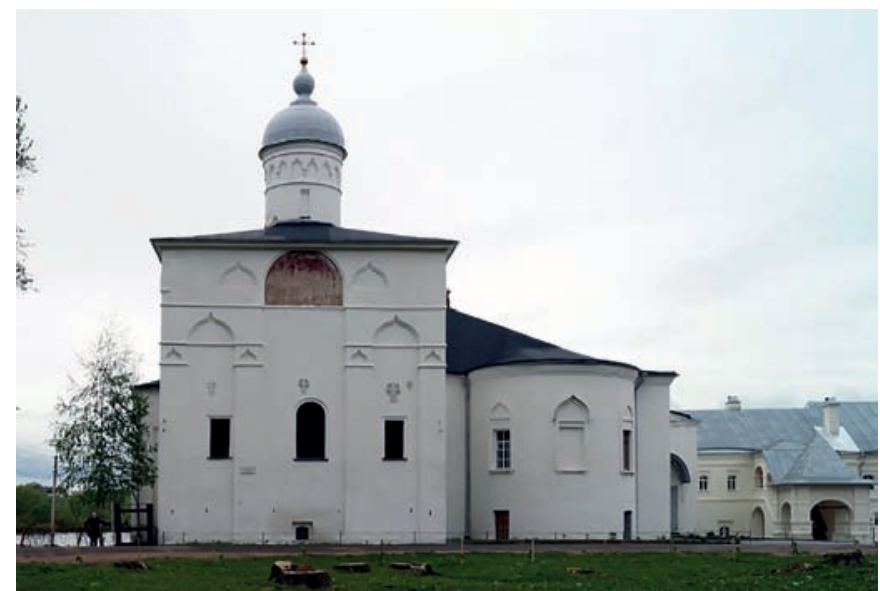

Рис. 6. Церковь Сретения с трапезной палатой (1533-1536). В настоящее время - университетский храм и музей истории письменности дохранилища археологических и культурных ценностей, но и драйвер развития городской среды. Помимо помещений для фондов, лабораторий и реставрационных мастерских в нём разместятся мультимедийные и интерактивные экспозиции, конференц-зал, студии для работы с детьми и молодёжью, интерактивное кафе. Ожидается увеличение количества посетителей до 50000 в год, увеличение числа иностранных посетителей до двух раз. Площадь участка 3532 кв.м.

Гуманитарный институт «Антоново» - Научно-гуманитарный центр «Антоново» - креативный кластер «Антоново»

Место, овеянное высочайшей духовностью: древний монастырь, основанный не позднее 1109 года, собор в честь Рождества Пресвятой Богородицы - третье по древности здание в Великом Новгороде. С площадки перед древними корпусами открываются заречные дали. В 1740 году по инициативе архиепископа Амвросия (Юшкевича) указом императрицы Анны Иоанновны при Антониевом монастыре была учреждена семинария по образцу Киевской духовной академии, ставшая культурным очагом северо-западных земель. В 1764 году в монастыре возведено двухэтажное каменное здание библиотеки.

Трудно найти место с более глубокими гуманитарными традициями, уже сейчас это один из самых красивых кампусов не только НовГУ, но и среди многих других региональных университетских кампусов. В отреставрированных помещениях келий и Настоятельского корпуса Антониева монастыря размещается «Центр реставрации монументальной живописи «Антоново», созданный в 2015 году на базе Реставрационных мастерских Новгородского музея-заповедника при поддержке Министерства культуры России. Связывая богатую культурную историю Антониева монастыря с будущим науки и образования, на его территории реализуется проект Всероссийского научно-образовательного духовно-просвети-

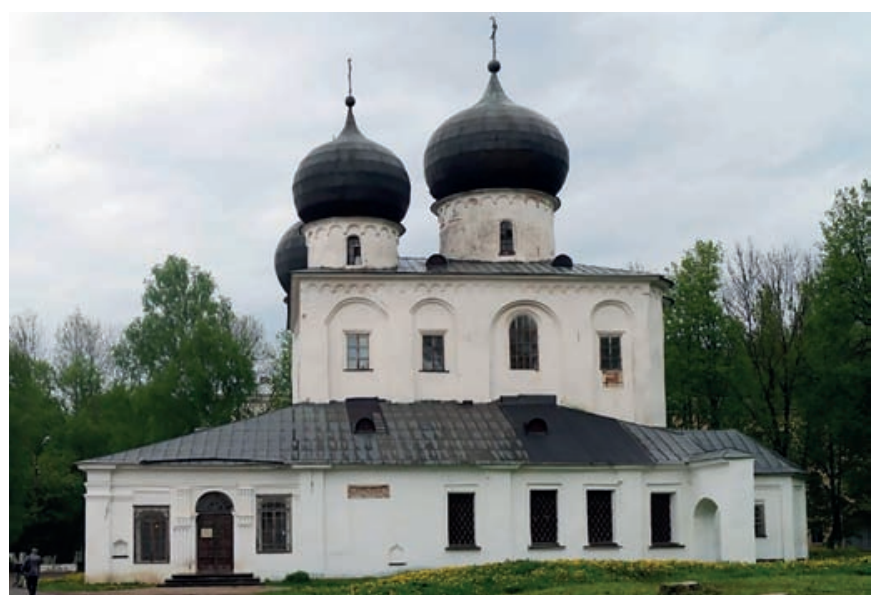

Pис. 7. Собор в честь Рождества Пресвятой Богородицы (1117-1119) 
тельского комплекса «Антоново». В Западном и Береговом корпусах монастыря работает Центр реставрации монументальной живописи, открыт учебно-научный музей Русской письменной культуры и книжности.

Как представляется, сложились предпосылки для формирования креативного кластера «Антоново» на основе указанных выше объектов как точки роста прилегающих территорий, нового центра научно-делового туризма. В частности, именно здесь целесообразно организовать головной офис Международного научно-практического центра археологии ${ }^{10}$ с сопровождающими сервисными и гостиничными службами, прерогативой которого как раз и будет развитие археологического туризма с привлечением к участию в раскопах зарубежных туристов, студентов, преподавателей, любителей археологии.

В креативный кластер «Антоново» предполагается включение Научно-гуманитарного центра - Гуманитарного института, Центра реставрации, а также гостиничного комплекса «Береста», парка Октября, стадиона «Электрон». Креативный кластер формируется как центр просвещения и отдыха. На этой основе построить концепцию переосмысления развития территории парка, университетского комплекса «Антоново», совместив просвещение, археологический и научно-деловой туризм, спортивно-оздоровительную программу.

Участки и здания перспективного освоения могут быть внесены в состав Креативного кластера в рамках программы Rurban Creative Lab ${ }^{11}$ по преобразованию городских и сельских территорий РФ в креативные кластеры под патронажем Финансового института развития в жилищной сфере (ДОМ. РФ) и Агентства стратегических инициатив (АСИ).

\section{Археологический квартал}

Основные подходы к формированию функционала Археологического квартала

Квартал создаётся по инициативе Российской академии наук и Новгородского музея-заповедника. На момент принятия решения предполагалось, что здесь откроют археологический парк под открытым небом, в котором будут показаны трассы средневековых мостовых, планы или виртуальные объёмы руинированных церквей, отдельные участки Немецкого двора и примыкающие к нему дворы новгородцев. Немецкий двор с конца XII по XVII век являлся торговым представительством Ганзы.

Проектное предложение предлагает предварительно разделить Археологический квартал на две зоны: зону сервисных функций на основе исторической существующей застройки и зону археологических раскопов, которая позже будет музеефицирована [6]. Именно на участках раскопов будут реализовываться программы археологического туризма.

${ }^{10}$ Авторское предложение в составе концепта Археологического кластера.

${ }^{11}$ http://www.giprogor.ru/news/8-news/999-programma-sozdaniyakreativnykh-klasterov-budet-realizovana-v-regionakh-rf.
Скорее всего, наиболее распространённой формой археологического туризма в квартале может также стать простое экскурсионное посещение археологических раскопок с элементами включённости туристов по заранее достигнутым договоренностям с руководством экспедиции. Это предполагает экскурсии по раскопу, демонстрацию находок с научными комментариями, участие в их первичной обработке, а также кратковременное участие в непосредственной раскопочной деятельности.

Главной функцией Археологического квартала на протяжении ближайших десяти-двадцати лет будут раскопки с последующей музеефикацией, реализация программ археологического и научно-делового туризма. Этот функционал станет практической

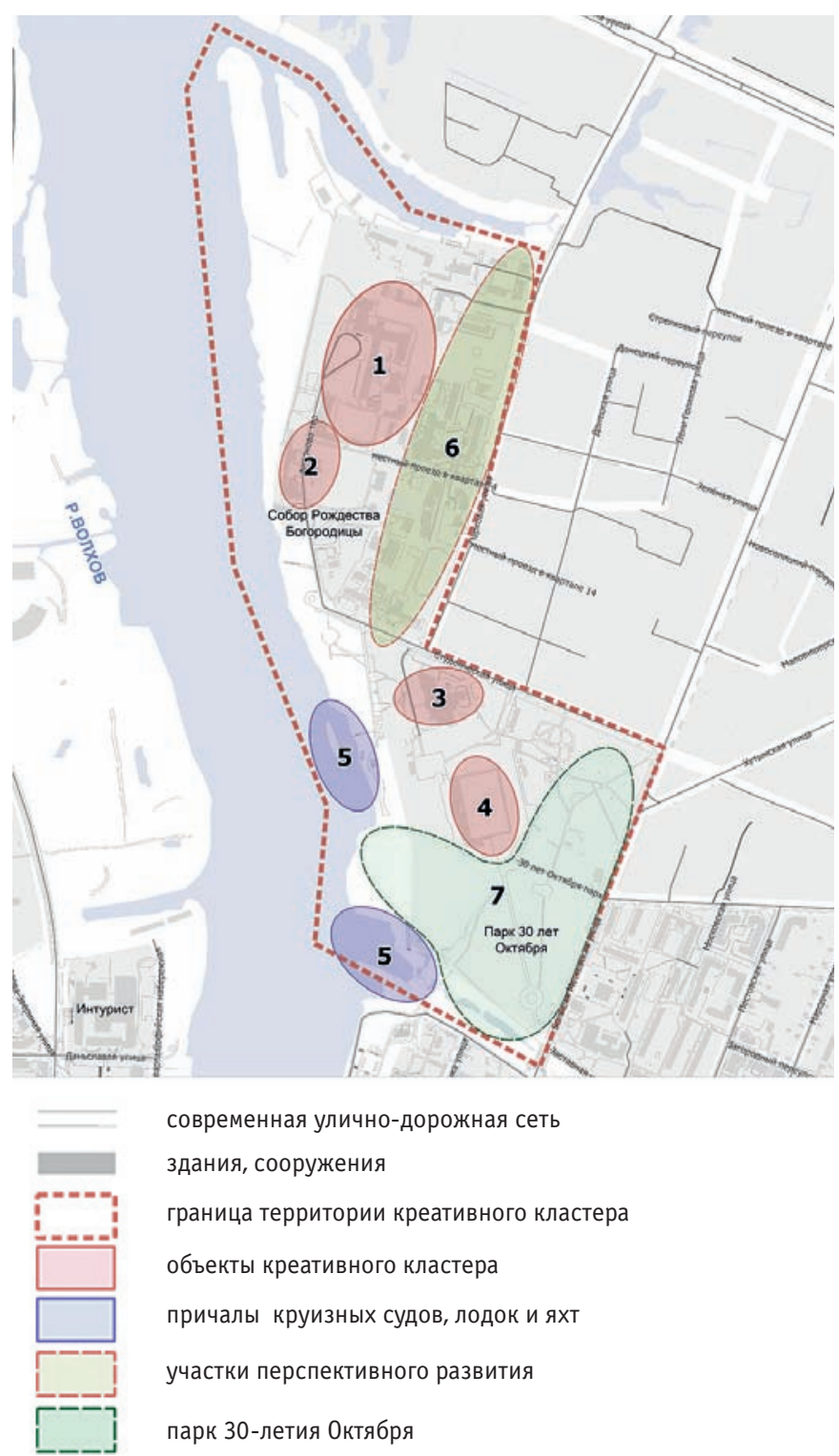

Рис. 8. Схема размещения объектов креативного кластера «Антонов»: 1 - корпуса гуманитарного института; 2 Центр реставрации; 3 -гостиница «Береста»; 4-стадион «Электрон»; 5 - причалы круизных судов, лодок и яхт; 6 участки перспективного развития с изменением функуционального назначения; 7 - парк 30-летия октября 


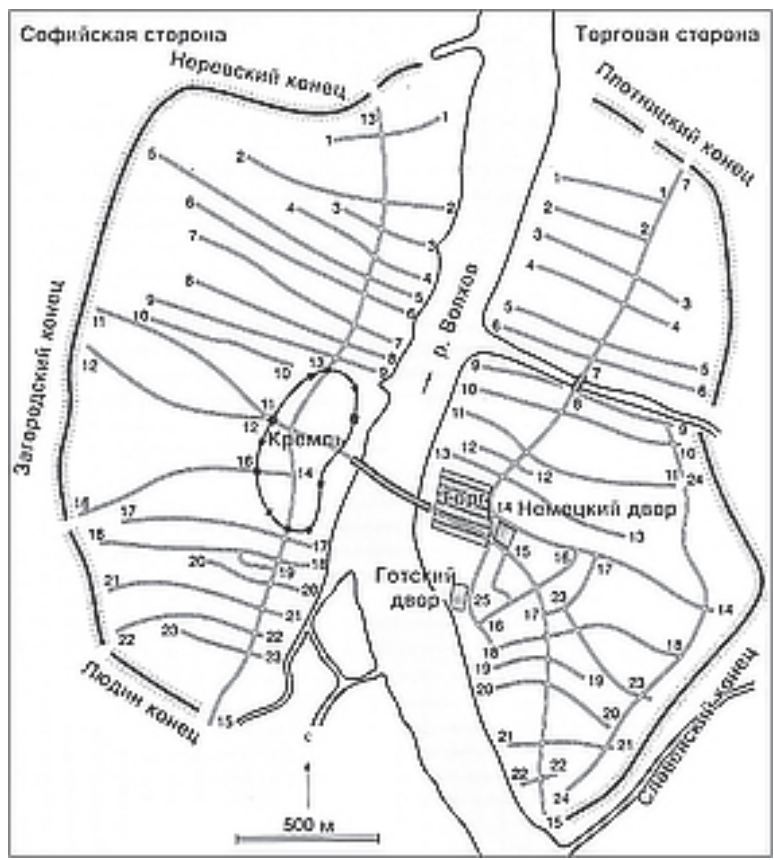

Pис. 9. Местоположение Немецкого двора на средневековом плане древнего Новгорода

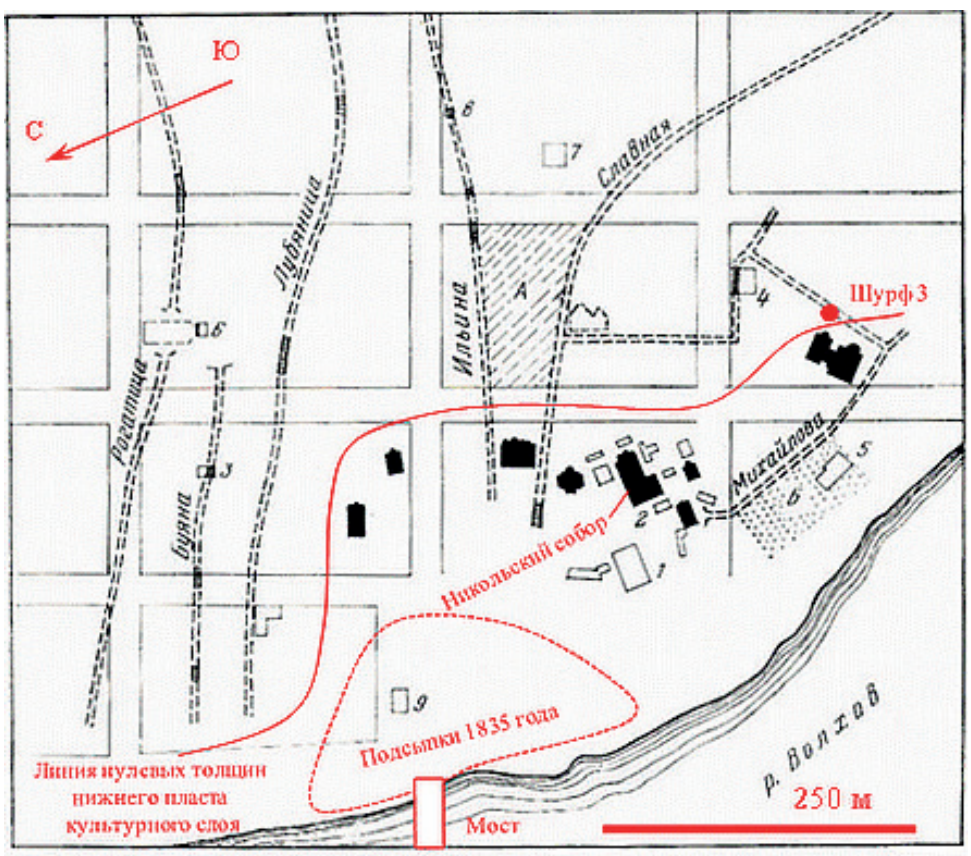

Pис. 10. План расположения Немецкого двора в Новгороде. A - немецкий двор, Б - Готский двор (источник: new.chronologia.org) частью Международного научно-практического центра археологии с привлечением кучастию в раскопах зарубежных туристов, студентов, преподавателей, любителей археологии.

\section{История возникновения археологической основы}

Археологического квартала

Археологический квартал расположен на Торговой стороне, к востоку от Ярославова Дворища, в квартале между современными улицами Большая Московская, Ильина, Михайлова, Никольская. В средневековом Новгороде здесь, где-то между древними улицами Ильиной и Славной, находился Немецкий двор, называемый в ганзейских источниках двором св. Петра, а рядом располагалась церковь Иоанна Крестителя [7].

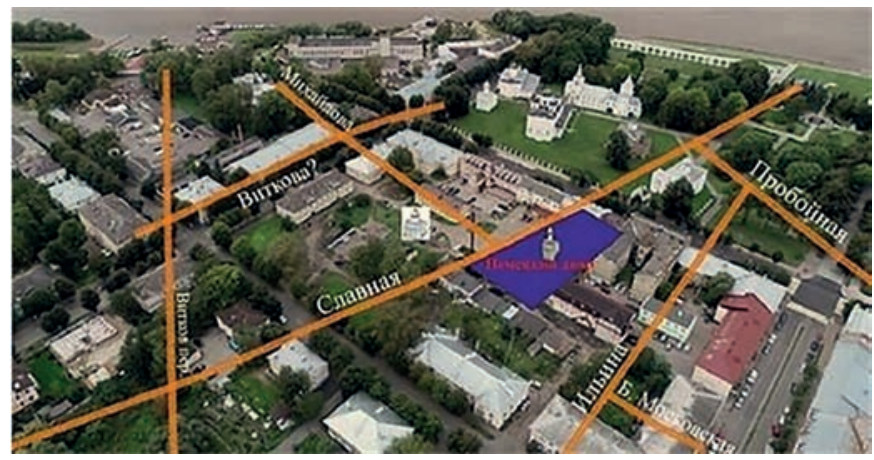

Рис. 11. Территория квартала 38 на Торговой стороне Великого Новгорода (между современными улицами Большая Московская, Ильина, Михайлова и Никольская). Немецкий двор, Ярославово Дворище и Торг в Великом Новгороде с трассировкой древних улиц (реконструкция) (источник: Институт археологии РАН)
Немецкий двор принадлежал Ганзейскому торговому союзу и имел автономное управление. Он был официальным представительством и торговой факторией немецких купцов в XII-XVI веках. Здесь по Уставу, который назывался Новогородская скра, были обязаны селиться иностранные купцы во время пребывания на новгородской земле. 0 существовании Немецкого двора известно из многочисленных русских и западноевропейских письменных источников.

Описание Немецкого двора с указанием его размеров и некоторых построек содержится в писцовой книге Великого Новгорода 1583 года, благодаря чему известна площадь двора (около 2000 кв. м), которая вряд ли менялась с момента его основания [8]. На территории двора находились каменная церковь св. Петра которая была доминантой всего Немецкого двора, поэтому его иногда называли Двор святого Петра - Peterhof. Кроме богослужений церковь св. Петра использовалась для хранения казны, ценностей, архива конторы и как самое надёжное и хорошо охраняемое здание - для хранения товаров. Во дворе находились жилые клети, амбары для хранения товаров, пивоварня, мельница, больничное помещение. Немецкий двор был окружён частоколом, ворота запирались на ночь, поддержание ограды в порядке было постоянной заботой ганзейского купечества. Материалом для строительства дворовых построек, вероятно, служило дерево, которое немецкие купцы согласно договору с Великим Новгородом могли рубить по берегам реки. Имеются сведения и о наличии во дворе кирпичного дома, для возведения которого Дерпт посылал в Великий Новгород своего мастера.

Местоположение немецкого двора было отмечено на новгородскихкартах, но весьмапроизвольно. Обнаружить точное расположение двора долгое время не удавалось, хотя были обнаружены 
следы других знаковых сооружений Новгородской республики.

Первые разведочные работы на участке новгородского квартала № 38 были проведены ещё в 1999 году. Тогда была открыта каменная постройка и фрагмент прилегающей улицы Славной, но сам Немецкий двор обнаружен не был. Новые раскопки начались уже после того, как в 2019 году администрация Великого Новгорода приняла решение о создании на исследуемой территории Археологического парка.

Во время возобновлённых раскопок в историческом центре Великого Новгорода археологи обнаружили границу Немецкого двора и часть стены соседней с Немецким двором церкви Иоанна Крестителя XIV века. Заложенные на участке шурфы и траншеи позволили археологам уточнить топографию средневековой застройки квартала. В 15 м от открытой церкви Иоанна Крестителя археологи обнаружили мостовую Большой Пробойной улицы Славенского конца древнего Новгорода с остатками межусадебного частокола Немецкого двора. Учёным удалось установить, что длина его восточной границы около 60 м. Раскопки 2020 года позволили археологам уточнить топографию этого района средневекового Новгорода и точно локализовать несколько улиц: «Поскольку теперь точно известно, где проходили средневековые улицы Славная и Михайлова, мы можем уверенно определить границы Немецкого двора: его

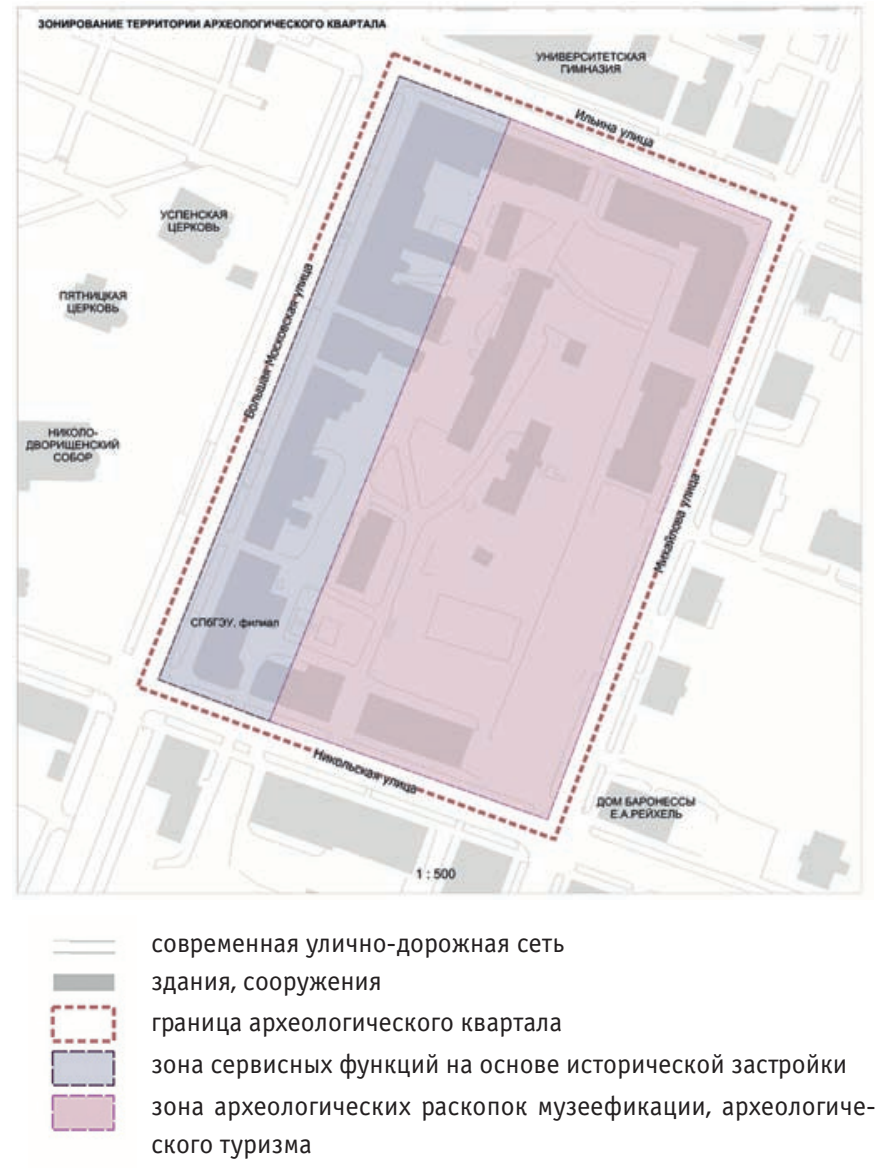

Рис. 12. Зонирование территории Археологического квартала восточная граница проходила по улице Славной около церкви Иоанна Крестителя, западная - под современными домами и тротуаром на Большой Московской улице. В 2021 году предполагается найти северную границу Немецкого двора, после чего будет возможно наметить план его дальнейшего изучения», - сообщил в личной беседе академик Пётр Гайдуков, директор Института археологии РАН. Проектная концепция Археологического квартала была в целом им поддержана.

\section{Проектная концепция Археологического квартала ${ }^{12}$}

Все здания, расположенные в квартале, где находился Немецкий двор, являются ценными градоформирующими объектами. Из них девять зданий являются объектами культурного наследия регионального значения, четыре здания обладают признаками объекта культурного наследия, два здания являются ценными элементами градостроительной среды. В настоящее время реализуются планы по созданию пешеходной зоны на улице Ильина. При этом необходимо решить вопрос ремонта фасадов домов: этот вопрос не так прост, как кажется, поскольку необходимо выявить и сохранить аутентичность и

\footnotetext{
12 Визуализация проектной разработки концепции Археологического квартала - архитектор П.К. Неустроева
}

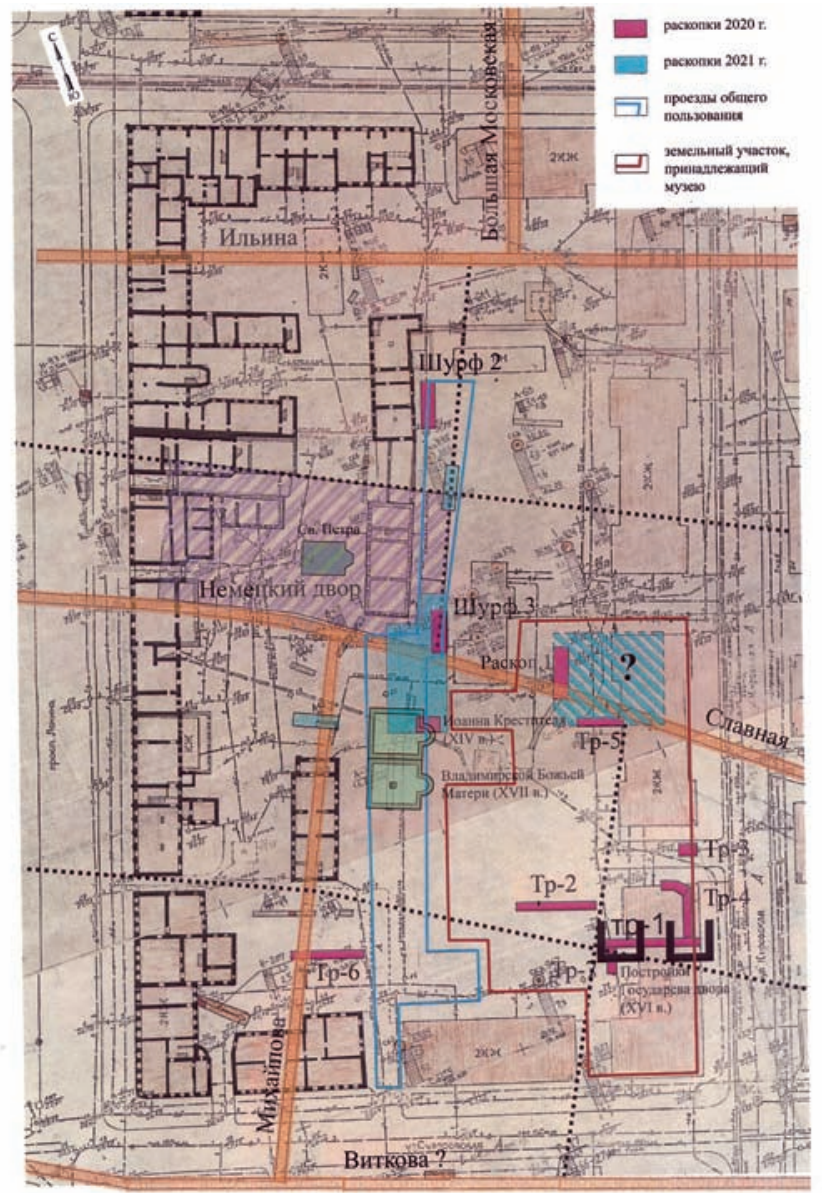

Рис. 13. Археологический план квартала с нанесением трасс древних дорог, шурфов, оснований древних храмов. Представлен академиком П.Г. Гайдуковым 
достоверность исторических фасадов, на финансирование чего собственники не способны [9].

Археологический квартал - часть концепции Археологического кластера, являющейся полноценной системой возрождения интереса к археологии. Основная функция этого квартала - использовать археологическое богатство Великого Новгорода для привлечения туристов, а также создать привлекательное общественное пространство для местных жителей. Концепция Археологического квартала основана на постоянных раскопках внутри него - это и функциональная, и эстетическая особенность формирования пространственной среды квартала. Такой режим существования площадки сам по себе является генератором событийности: раскопки ведутся каждый год в новой точке, они не повторяются, и только раз в год можно увидеть открытые слои определённого века. На следующий год место раскопок музеефицируется в том или ином виде.

Концепция предлагает осуществлять освоение квартала в два этапа. Первый этап, длительностью до двадцати лет, совпадает с периодом проведения археологических работ на данном участке. Второй начинается, когда все раскопки окончены, по полученным данным воссоздаются примерные очертания старого города (с помощью голограмм или легко-

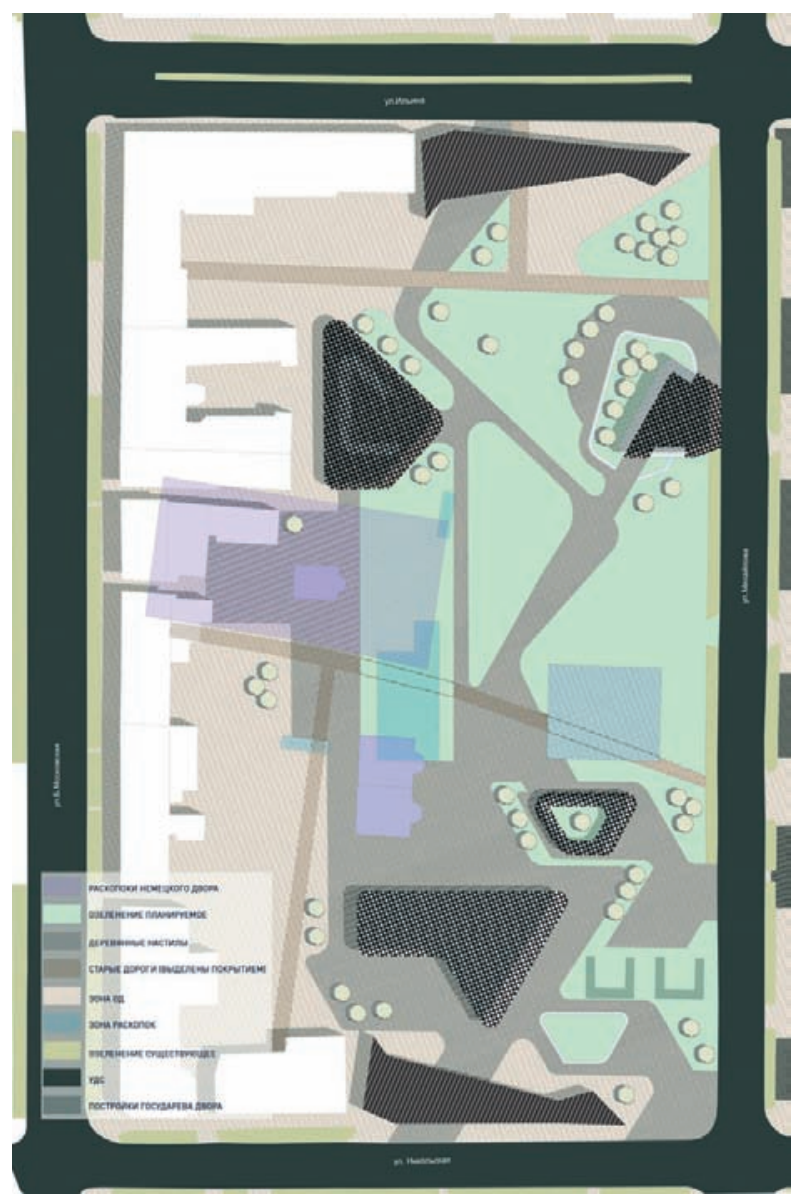

Рис. 14. Проектное видение Археологического квартала. План по завершении второго этапа. Архитектор П.К. Неустроева возводимых конструкций) и строится здание музея. Общественное пространство, созданное в квартале, сохраняется, но трансформируется как во время первого этапа, так и при переходе от первого этапа ко второму.

Первый этап - период активных археологических изысканий:

1) подготовка площадки: вынос инженерных объектов, перекладка сетей, снос не ценных строений;

2) формирование массива исторических строений, выходящих на улицу Большую Московскую, по системе «двойной фасад»: фасады, которые «смотрят» внутрь археологического квартала, путём расчистки от поздних пристроек и реставрации тоже становятся полноценными главными, таким образом, создаётся вторая пешеходная «улица» внутри квартала. Здания приспосабливаются под нужды квартала: кафе, магазины, филиал археологического факультета, гостиницы для археологических туристов, филиал музея и т.д.;

3) создание археологического парка, с открытой «экспозицией», которая меняется каждый год по мере завершения раскопок на плановом участке;

4) создание основных исторических доминант квартала путем визуализации утраченных построек - храма Святого Петра на Немецком дворе, церквей Иоанна Крестителя и Вла-

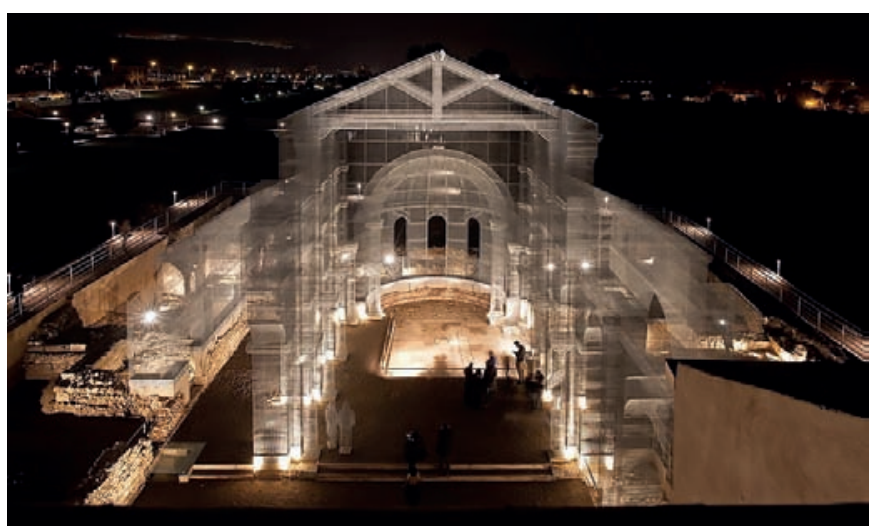

Рис. 15. Храм в Археологическом парке Сипонто. Город Манфредония, Италия

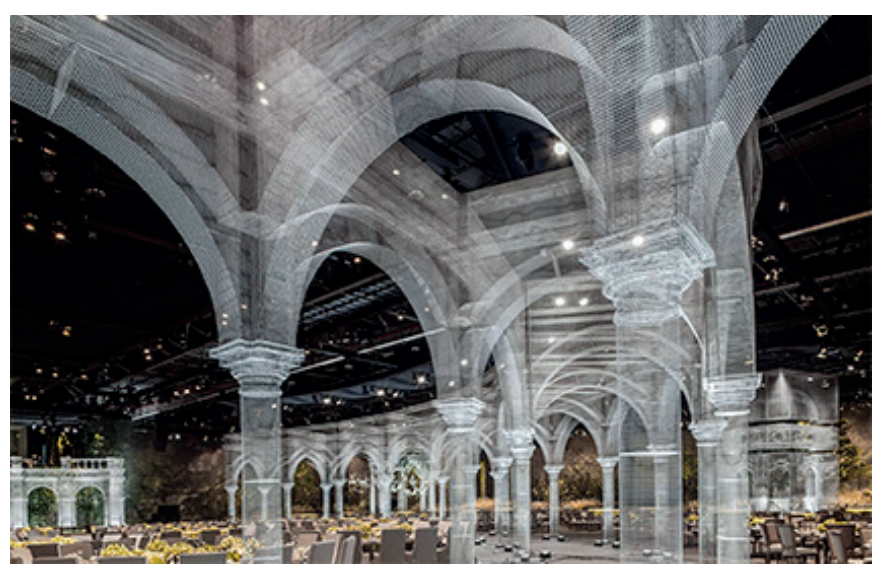

Рис. 16. Композиция в Абу-Даби, ОАЭ 
димирской иконы Божьей матери - средствами современных высоких технологий показа таких объектов как в полноразмерном масштабе, так и в виде голограмм в специальных павильонах. Поскольку это ещё достаточно новая форма воссоздания утраченных зданий, приведём такие примеры, как создаваемые итальянским архитектором Эдуардо Трисольди [10] пространственные композиции из арматуры, проволоки и металлической сетки различной толщины: в одном случае это воссоздание базиликального храма в Археологическом парке Сипонто в Италии, во втором - фантазийная композиция на темы итальянской архитектуры в Абу-Даби (рис. 15, 16);

5) обозначение древних утраченных дорог с помощью мощения, воссоздающего древнюю кладку;

6) обозначение местоположения и очертаний Государева двора;

7) создание современного общественного пространства, трансформируемого из года в год в соответствии с планом раскопов с помощью деревянных настилов, перемещаемых $\mathrm{MA}^{\prime}{ }^{\prime}{ }^{13}{ }^{13}$, перемещаемого озеленения; устройство площадок для отдыха и встреч с зоной WI-FI, открытого амфитеатра для проведения лекций и т. п. - всех составляющих современного общественного пространства;

9) использование современных технологий проведения раскопок, например, лазерного сканирования, для создания новых аттракционов с целью привлечения молодёжи;

10) организация пространства квартала для круглосуточного использования, поскольку при проведении стратегических сессий с жителями и представителями профессиональных сообществ прозвучал запрос на круглосуточные общественные пространства. Предлагаемый режим эксплуатации архквартала: экспозиция под открытым небом доступна всегда, освещение гарантирует безопасность, несколько круглосуточных кафе добавят привлекательность этому месту, голограммы утраченных храмов рассчитаны на ночную экспозицию.

Второй этап - «постраскопочный» период, завершение реализации уникального Археологического квартала:

${ }^{13}$ МАФ - Малые архитектурные формы

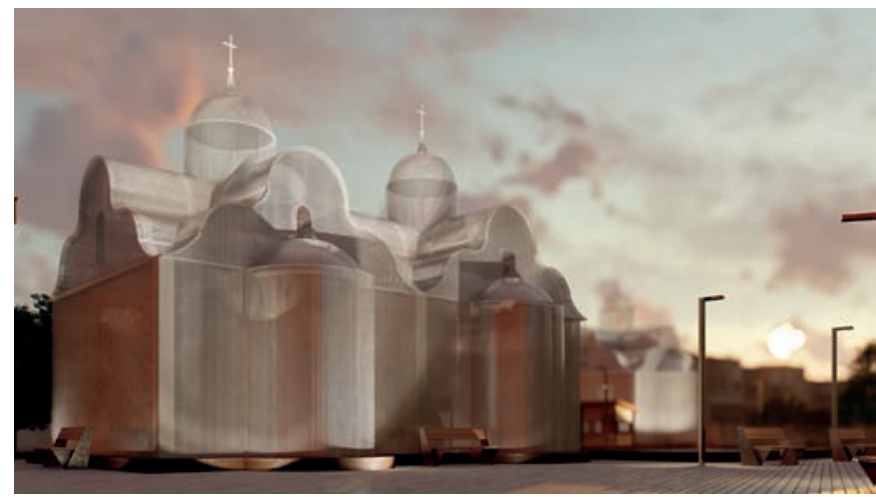

Рис. 17. Технологическое воссоздание древних храмов. Проектная визуализация. Архитектор П.К. Неустроева
1) создание музейного комплекса;

2) создание разрытых и открытых экспозиций с помощью разного рода музеефикации подземных раскопок. Различные методы музеефикации уже давно известны и широко распространены как в мире, так и в России (Музей московской археологии, археологический заповедник Херсонес);

3) преобразование общественного пространства в постоянное: прокладка дорожной сети, озеленение;

4) воссоздание среды средневекового двора в центре этого общественного пространства.

Представляется, что в результате завершения работ по Археологическому кварталу, его пространства могут выглядеть примерно так, как это изображено на рисунках 17, 18.

\section{Заключение}

0сновные концептуальные направления по развитию туризма Великого Новгорода заключаются в создании туристического продукта мирового уровня, формируемого на базе его уникальных особенностей. Великий Новгород - город метакультурного пространства России, перекрёсток культур, эпох, цивилизаций, центр археологии, город всемирного наследия Юнеско и обретённых артефактов. В Концепции предлагается ревитализация исторического центра путём формирования городского пространства, отражающего связь поколений от прошлого к будущему, от истории и археологии к туристическому центру мирового уровня. Формирование основных идей по благоустройству территории, в рамах Концепции ревитализации туристического центра Великого Новгорода основано на изучении истории градостроительного и архитектурно-планировочного развития территорий.

Предлагаемый концепт Археологического кластера органически включается в общую Концепцию ревитализации туристического центра, отвечая требованию развития одного из основных видов туризма по ФЦП «Развитие внутреннего и въездного туризма в Российской Федерации (2019-2025 годы)» - культурно-познавательный туризму.

Археологический квартал, будучи составной частью Археологического кластера, углубляет этот вид туризма в части спе-

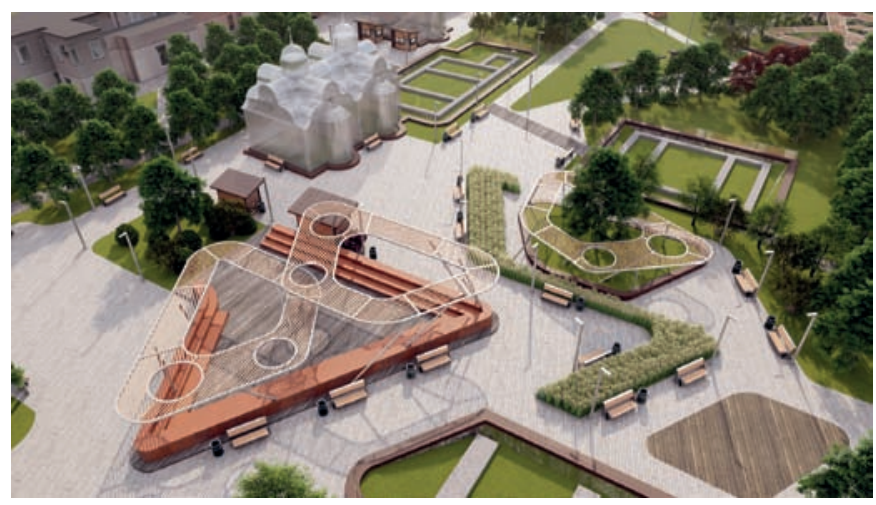

Рис. 18. Проектная визуализация: общественное пространство квартала, воссоздание храмовых построек, музеефикация фундаментов. Архитектор П.К. Неустроева 
циализации научного и делового туризма, объединяя их в археологическом туризме как в специальных программах, так и в программах детского и молодёжного образовательного туризма, научных фестивалей, «доступной» археологии». При этом функционал квартала прямым образом будет направлен и на улучшение качества городской среды и обслуживания как жителей прилегающих кварталов, так и гостей и туристов города.

\section{Лuтература}

1. Щипков, А. Сакральная география России: от Херсонеса до Соловков [Электронный ресурс] / А. Щипков // Православие.ру. Сайт. - Режим доступа: https://pravoslavie.ru/93842. html (дата обращения 15.05.2021).

2. Гончарова, Е.Н. Современное состояние археологического туризма на международном рынке туристских услуг [Электронный ресурс] / Е.Н. Гончарова // Материалы научнометодических чтений ПГЛУ. 2015. Пятигорск, 13-14 января 2015 года. - Пятигорск, ПГЛУ, 2015. - С. 43-47. - Режим доступа: https://www.elibrary.ru/item.asp?id=24600994 (дата обращения 10.05.2021).

3. Янин, В.Л. Археология и археологический туризм / В.Л. Янин. - М., 2006.

4. Бурков, С.Б. Туристические возможности археологического наследия: теория и практика [Электронный ресурс] / С.Б. Бурков // Материалы I международной научной конференции «Глобализация и туризм: проблемы взаимодействия». Саратов, 15-16 апреля 2009 г. - Режим доступа: https:// tourlib.net/statti_tourism/burkov.htm (дата обращения 10.05.2021).

5. Качнов, С.Ю. Перекрестие меча из раскопа на ул. Большая Московская в Великом Новгороде [Электронный ресурс] / С. Ю. Каинов, 0.М. Олейников // Российская археология. 2020. - № 2. - С. 167-176 // Журналы РАН. - Режим доступа: http://ras.jes.su/ra/s086960630009080-7-1 (дата обращения 13.05.2021). DOI: 10.31857/S086960630009080-7.

6. Лопатин, H.B. Археологический парк как форма сохранения, изучения и популяризации объекта культурного наследия (на примере Труворова городища) / Н.В. Лопатин, А.В. Михайлов, В.А. Яковлева // Вестник Псковского государственного университета. Серия: Социально-гуманитарные науки, 2013. - С. 17-24.

7. Новгород и Ганза. История [Электронный ресурс] / По материалам историка Василия Фёдоровича Андреева // Великий Новгород. Сайт. - Режим доступа: https:// www.visitnovgorod.ru/novgorod/discover_novgorod/ The_city_of_Hansa/novgorod-i-ganza.html (дата обращения 20.05.2021).

8. Рыбина, E.А. Возникновение и местоположение Готского и Немецкого дворов [Электронный ресурс] / E.А. Рыбина // ВикиЧтение. - Режим доступа://https://history.wikireading. ru/318586 (дата обращения 18.05.2021)(.

9. Шалина, Д.С. Реновация, редевелопмент, ревитализация и джентрификация городского пространства / Д.С. Шалина,
Н.Р. Степанова // Фундаментальные исследования. - 2019. - № 12-2. - С. 285-289.

10. Здания-призраки Эдоардо Тресольди, заставляющие переосмыслить привычное видение мира // TravelAsk.Ru. Режим доступа: https://travelask.ru/blog/posts/21893zdaniya-prizraki-edoardo-tresoldi (дата обращения 25.04.2021).

\section{References}

1. Shchipkov A. Sakral'naya geografiya Rossii: ot Khersonesa do Solovkov [Sacred geography of Russia: from Chersonesos to Solovki]. Pravoslavie.ru. Website. Access mode: https:// pravoslavie.ru/93842.html (Accessed 05/15/2021). (In Russ.)

2. Goncharova E.N. Sovremennoe sostoyanie arkheologicheskogo turizma na mezhdunarodnom rynke turistskikh uslug [The current state of archaeological tourism on the international market of tourist services]. In: Materialy nauchno-metodicheskikh chtenii PGLU. 2015. Pyatigorsk, 13-14 yanvarya 2015 goda [Materials of scientific and methodical readings of PSLU. 2015. Pyatigorsk, January 13-14, 2015]. Pyatigorsk, PGLU Publ., 2015, pp. 43-47. Access mode: https://www.elibrary.ru/item.asp?id=24600994 (Accessed 05/10/2021). (In Russ.)

3. Yanin V.L. Arkheologiya i arkheologicheskii turizm [Archeology and archaeological tourism]. Moscow, 2006. (In Russ.)

4. Burkov S.B. Turisticheskie vozmozhnosti arkheologicheskogo naslediya: teoriya i praktika [Tourist opportunities of archaeological heritage: theory and practice]. In: Materialy I mezhdunarodnoi nauchnoi konferentsii "Globalizatsiya i turizm: problemy vzaimodeistviya". Saratov, 15-16 aprelya $2009 \mathrm{~g}$. [Proceedings of the I International Scientific Conference "Globalization and Tourism: Problems of Interaction". Saratov, April 15-16, 2009]. Access mode: https://tourlib.net/statti_tourism/burkov.htm (Accessed 05/10 /2021). (In Russ.)

5. Kainov S. Yu., Oleinikov 0. M. Perekrestie mecha iz raskopa na ul. Bol'shaya Moskovskaya v Velikom Novgorode [Crosshair of a sword from the excavation site at ul. Bolshaya Moskovskaya in Veliky Novgorod]. In: Rossiiskaya arkheologiya [Russian archeology], 2020, no. 2, pp. 167-176, in: Zhurnaly RAN [Journals of the Russian Academy of Sciences]. Access mode: http://ras. jes.su/ra/s086960630009080-7-1 (Accessed 05/13/2021). DOI: 10.31857/S086960630009080-7. (In Russ.)

6. Lopatin N.V., Mikhailov A.V., Yakovleva V.A. Arkheologicheskii park kak forma sokhraneniya, izucheniya i populyarizatsii ob"ekta kul'turnogo naslediya (na primere Truvorova gorodishcha) [Archaeological park as a form of preservation, study and popularization of a cultural heritage site (on the example of Truvorov settlement)]. In: Vestnik Pskovskogo gosudarstvennogo universiteta. Seriya: Sotsial'no-gumanitarnye nauki [Bulletin of the Pskov State University. Series: Social Sciences and Humanities], 2013, pp. 17-24. (In Russ.) 
7. Novgorod i Ganza. Istoriya. Po materialam istorika Vasiliya Fedorovicha Andreeva [Novgorod and Hansa. History. Based on materials from the historian Vasily Fedorovich Andreev]. Velikii Novgorod. Website. Access mode: https://www.visitnovgorod. ru/novgorod/discover_novgorod/The_city_of_Hansa/ novgorod-i-ganza.html (Accessed 05/20/2021). (In Russ.)

8. Rybina E.A. Vozniknovenie i mestopolozhenie Gotskogo i Nemetskogo dvorov [The occurrence andlocation of the Gotsky and German courtyards]. VikiChtenie. Access mode: //https:// history.wikireading.ru/318586 (Accessed 05/18/2021). (In Russ.)
9. Shalina D.S., Stepanova N.R. Renovatsiya, redevelopment, revitalizatsiya i dzhentrifikatsiya gorodskogo prostranstva [Renovation, redevelopment, revitalization and gentrification of urban space]. In: Fundamental'nye issledovaniya [Fundamental research], 2019, no. 12-2, pp. 285-289. (In Russ., abstr.in Engl.)

10. Zdaniya-prizraki Edoardo Tresol'di, zastavlyayushchie pereosmyslit' privychnoe videnie mira [Ghost buildings of Edoardo Tresoldi, forcing to rethink the usual vision of the world]. TravelAsk.Ru. Website. Access mode: https://travelask. ru/blog/posts/21893-zdaniya-prizraki-edoardo-tresoldi (Accessed 04/25/2021). (In Russ.)

Кулешова Галина Ивановна (Москва). Советник РААСН, академик МААМ (Московское отделение). Ученый секретарь ФГБУН Отделение научно-исследовательских работ ГИПРОНИИ РАН (117971, Москва, ул. Губкина, д. 3. ОНИР ГИПРОНИИ РАН). Эл. почта: kuleshgal@yandex.ru.

Kuleshova Galina I. (Moscow). Advisor of RAACS, Academician of the Moscow branch of the International Academy of Architecture. Scientific Secretary at the Research Department of Department of research works of the Head Design and Research Institute of the Russian Academy of Sciences (3 Gubkina st, Moscow, 117971. GIPRONII RAN). E-mail: kuleshgal@yandex.ru. 